Acta Crystallographica Section E

Structure Reports

Online

ISSN 1600-5368

\section{(3S,6S)-3-Benzyloxymethyl-6-methyl- 1,4-dioxane-2,5-dione}

The chiral centres in the dilactone moiety of the title compound, $\mathrm{C}_{13} \mathrm{H}_{14} \mathrm{O}_{5}$, are in the configuration $3 S, 6 S$. The ring itself has a boat conformation. $\mathrm{C}-\mathrm{H}$. . O interactions link the molecules into a chain in the [010] direction.

\section{Comment}

Department of Crystal and Structural Chemistry, Utrecht University, Padualaan 8, $3584 \mathrm{CH}$ Utrecht, The Netherlands, and ${ }^{\mathbf{b}}$ Department of Pharmaceutics, Utrecht Institute for Pharmaceutical Sciences (UIPS), Faculty of Pharmaceutical Sciences, Utrecht University, PO Box 80082, 3508 TB Utrecht,

The Netherlands

Correspondence e-mail:

h.kooijman@chem.uu.nl

\section{Key indicators}

Single-crystal X-ray study

$T=150 \mathrm{~K}$

Mean $\sigma(\mathrm{C}-\mathrm{C})=0.003 \AA$

$R$ factor $=0.036$

$w R$ factor $=0.095$

Data-to-parameter ratio $=9.7$

For details of how these key indicators were automatically derived from the article, see http://journals.iucr.org/e.
(C) 2005 International Union of Crystallography Printed in Great Britain - all rights reserved
The structure of the title compound was determined in the course of our investigations towards a better understanding of the regioselectivity observed in the ring-opening polymerization of the title compound, (I) (Leemhuis et al., 2005).

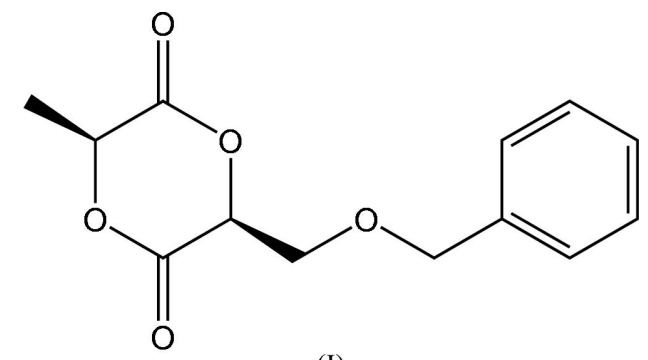

(I)

The sample from which the crystals were grown was synthesized from enantiopure (2S)-3-benzyloxy-2-hydroxy propanoic acid and $( \pm)$ - $\alpha$-bromopropionylbromide. The stereoisomers of this reaction were separated by column chromatography. The absolute configuration of the chiral centres in the lactide ring was chosen in accordance with the enantiopure starting material. Both chiral atoms, C2 and C5, are in the $S$ configuration. The structure of the $R, S$ stereoisomer has also been determined and is published in a separate report (Kooijman et al., 2005). The lactide ring has a boat conformation, as is common for $3 S, 6 \mathrm{~S}$-substituted lactides (e.g. Bolte et al., 1994). All ring substituents are in the equatorial position. The lowest asymmetry parameters (Duax \& Norton, 1975) are $\Delta C_{\mathrm{s}}(\mathrm{C} 2)=9.74(16)^{\circ}$ and $\Delta C_{\mathrm{s}}(\mathrm{O} 2-\mathrm{C} 1)=7.1(2)^{\circ}$; all other asymmetry parameters have values $27^{\circ}$ or higher. The Cremer \& Pople (1975) puckering parameters are $\theta=$ $90.59(18)^{\circ}$ and $\varphi=125.54(18)^{\circ}$; the ideal values for the observed boat conformation are $\theta=90^{\circ}$ and $\varphi=120^{\circ}$. The link between the two ring systems has an all-trans conformation, with the exception of the $\mathrm{C}-\mathrm{Ph}$ bond.

The packing displays some relatively short $\mathrm{C}-\mathrm{H} \cdots \mathrm{O}$ contacts, geometric details of which are given in Table 2. Both axial $\mathrm{H}$ atoms of the lactide ring, $\mathrm{H} 2$ and $\mathrm{H} 5$, have a short contact with keto atom $\mathrm{O} 1\left(-x,-\frac{1}{2}+y, 1-z\right)$. Atom $\mathrm{H} 5$ is also involved in a contact with another $\mathrm{O} 1$ atom, at equivalent position $(x, y-1, z)$. The sum of the intermolecular angles involving atom $\mathrm{H} 5$ is $359^{\circ}$, indicating a bifurcated character.
Received 25 February 2005 Accepted 4 March 2005 Online 11 March 2005 


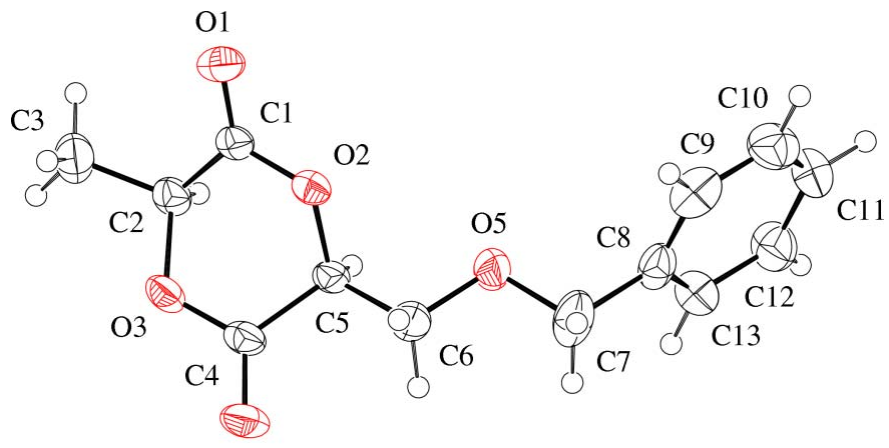

Figure 1

$\mathrm{O} 4$

Atomic displacement plot (Spek, 2003) of the title compound, showing the atom-numbering scheme. The displacement ellipsoids are drawn at the $50 \%$ probability level.

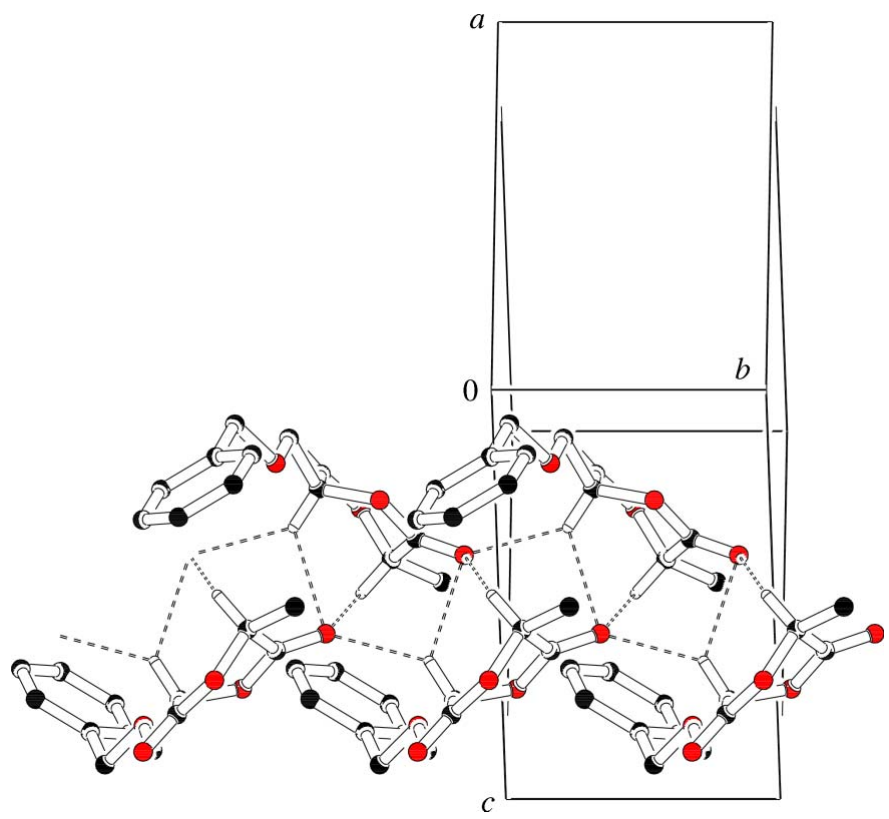

Figure 2

Short contacts $\left[\mathrm{C} 2-\mathrm{H} 2 \cdots \mathrm{O} 1\left(-x, \frac{1}{2}-y, 1-z\right), \mathrm{C} 5-\mathrm{H} 5 \cdots \mathrm{O} 1\left(-x, \frac{1}{2}-y\right.\right.$, $1-z)$ and $\mathrm{C} 5-\mathrm{H} 5 \cdots \mathrm{O} 1(x, y-1, z)$, dashed lines] link the molecules into an infinite chain in the [010] direction.

The $\mathrm{C}-\mathrm{H} \cdots \mathrm{O}$ contacts join the molecules into an infinite chain in the [010] direction (Fig. 2).

\section{Experimental}

The synthesis of the title compound is described elsewhere (Leemhuis et al., 2003). Crystals were grown from a solution in methyl-tertbutyl ether to which some hexane was added. This solution was placed in a refrigerator and after $1 \mathrm{~h}$ colourless crystals were formed.

\section{Crystal data}

$$
\begin{aligned}
& \mathrm{C}_{13} \mathrm{H}_{14} \mathrm{O}_{5} \\
& M_{r}=250.24 \\
& \text { Monoclinic, } P 2_{1} \\
& a=8.944(2) \AA \\
& b=5.9400(10) \AA \\
& c=12.559(3) \AA \\
& \beta=107.905(12)^{\circ} \\
& V=634.9(2) \AA^{3} \\
& Z=2
\end{aligned}
$$

\section{Data collection}

Nonius KappaCCD area-detector diffractometer

$\varphi$ scans, and $\omega$ scans with $\kappa$ offsets Absorption correction: none

16869 measured reflections

1590 independent reflections

\section{Refinement}

Refinement on $F^{2}$

$R\left[F^{2}>2 \sigma\left(F^{2}\right)\right]=0.036$

$w R\left(F^{2}\right)=0.095$

$S=1.08$

1590 reflections

164 parameters

$\mathrm{H}$-atom parameters constrained

$$
\begin{aligned}
& 1430 \text { reflections with } I>2 \sigma(I) \\
& R_{\text {int }}=0.093 \\
& \theta_{\max }=27.5^{\circ} \\
& h=-11 \rightarrow 11 \\
& k=-7 \rightarrow 7 \\
& l=-16 \rightarrow 16
\end{aligned}
$$

Table 1

Selected geometric parameters $\left(\AA{ }^{\circ}\right)$.

\begin{tabular}{lrlr}
\hline $\mathrm{O} 2-\mathrm{C} 1$ & $1.337(2)$ & $\mathrm{O} 3-\mathrm{C} 2$ & $1.457(2)$ \\
$\mathrm{O} 2-\mathrm{C} 5$ & $1.446(2)$ & $\mathrm{O} 3-\mathrm{C} 4$ & $1.340(2)$ \\
$\mathrm{C} 1-\mathrm{O} 2-\mathrm{C} 5$ & $116.91(14)$ & $\mathrm{C} 2-\mathrm{O} 3-\mathrm{C} 4$ & $117.76(15)$ \\
& & & \\
$\mathrm{C} 7-\mathrm{O} 5-\mathrm{C} 6-\mathrm{C} 5$ & $-165.8(2)$ & $\mathrm{C} 4-\mathrm{C} 5-\mathrm{C} 6-\mathrm{O} 5$ & $166.08(16)$ \\
$\mathrm{C} 6-\mathrm{O} 5-\mathrm{C} 7-\mathrm{C} 8$ & $172.4(2)$ & $\mathrm{O} 5-\mathrm{C} 7-\mathrm{C} 8-\mathrm{C} 9$ & $84.7(3)$ \\
\hline
\end{tabular}

Table 2

Hydrogen-bond geometry $\left(\AA,{ }^{\circ}\right)$.

\begin{tabular}{lllll}
\hline$D-\mathrm{H} \cdots A$ & $D-\mathrm{H}$ & $\mathrm{H} \cdots A$ & $D \cdots A$ & $D-\mathrm{H} \cdots A$ \\
\hline $\mathrm{C} 2-\mathrm{H} 2 \cdots \mathrm{O} 1^{\mathrm{i}}$ & 1.00 & 2.57 & $3.247(3)$ & 125 \\
$\mathrm{C} 5-\mathrm{H} 5 \cdots \mathrm{O} 1^{\mathrm{ii}}$ & 1.00 & 2.32 & $3.134(3)$ & 137 \\
$\mathrm{C} 5-\mathrm{H} 5 \cdots{ }^{\mathrm{i}}$ & 1.00 & 2.54 & $3.272(3)$ & 130 \\
\hline
\end{tabular}

Symmetry codes: (i) $-x, y-\frac{1}{2},-z+1$; (ii) $x, y-1, z$.

In the absence of significant anomalous scatterers, Friedel pairs were averaged. The methyl group was refined as a rigid group, allowing for rotation around the $\mathrm{C}-\mathrm{C}$ bond. $\mathrm{H}$ atoms were treated as riding, with $\mathrm{C}-\mathrm{H}$ distances of $0.95-1.00 \AA$ and $U_{\text {iso }}(\mathrm{H})$ values set to 1.5 or 1.2 times $U_{\text {eq }}$ of the carrier atom for methyl and other $\mathrm{H}$ atoms, respectively.

Data collection: COLLECT (Nonius, 1998); cell refinement: DENZO (Otwinowski \& Minor, 1997); data reduction: DENZO; program(s) used to solve structure: SHELXS86 (Sheldrick, 1986); program(s) used to refine structure: SHELXL97 (Sheldrick, 1997); molecular graphics: PLATON (Spek, 2003); software used to prepare material for publication: PLATON.

This work was supported in part (ALS and ML) by the Council for the Chemical Sciences of the Netherlands Organization for Scientific Research (CW-NWO) with financial aid from the Netherlands Technology Foundation (CW/STW 790.35.622).

\section{References}

Bolte, M., Beck, H., Nieger, M. \& Egert, E. (1994). Acta Cryst. C50, 1717-1721. Cremer, D. \& Pople, J. A. (1975). J. Am. Chem. Soc. 97, 1354-1358.

Duax, W. L. \& Norton, D. A. (1975). Atlas of Steroid Structure, Vol. 1. New York: IFI/Plenum. 


\section{organic papers}

Kooijman, H., Leemhuis, M., van Nostrum, C. F., Hennink, W. E. \& Spek, A. L. (2005). Acta Cryst. E61, o898-o900.

Leemhuis, M., van Nostrum, C. F. \& Hennink, W. E. (2005). In preparation.

Leemhuis, M., van Steenis, J. H., van Uxem, M. J., van Nostrum, C. F., Hennink, W. E. (2003). Eur. J. Org. Chem. pp. 3344-3349.

Nonius (1998). COLLECT. Nonius BV, Delft, The Netherlands.
Otwinowski, Z. \& Minor, W. (1997). Methods in Enzymology, Vol. 276, Macromolecular Crystallography, Part A, edited by C. W. Carter Jr \& R. M. Sweet, pp. 307-326. New York: Academic Press.

Sheldrick, G. M. (1986). SHELXS86. University of Göttingen, Germany. Sheldrick, G. M. (1997). SHELXL97. University of Göttingen, Germany. Spek, A. L. (2003). J. Appl. Cryst. 36, 7-13. 